Institute of $\mathbf{F}_{\text {ood and }} \mathbf{A}_{\text {gricultural }} \mathbf{S}_{\text {ciences }}$

\title{
European Corn Borer, Ostrinia nubilalis (Hubner) (Insecta: Lepidoptera: pyralidae) ${ }^{1}$
}

J. L. Capinera ${ }^{2}$

\section{Distribution}

First found in North America near Boston, Massachusetts in 1917, European corn borer, Ostrinia nubilalis (Hubner), now has spread as far west as the Rocky Mountains in both Canada and the United States, and south to the Gulf Coast states. European corn borer is thought to have originated in Europe, where it is widespread. It also occurs in northern Africa. The North American European corn borer population is thought to have resulted from multiple introductions from more than one area of Europe. Thus, there are at least two, and possibly more, strains present. This species occurs infrequently in Florida.

\section{Life Cycle and Description}

The number of generations varies from one to four, with only one generation occurring in northern New England and Minnesota and in northern areas of Canada, whereas three to four generations occur in Virginia and other southern locations. In many areas generation number varies depending on weather, and there is considerable adaptation for local climate conditions even within strains. European corn borer overwinters in the larval stage, with pupation and emergence of adults in early spring. Diapause apparently is induced by exposure of last instar larvae to long days, but there also is a genetic component. Moth flights and oviposition usually occur during June-July and August-September in areas with one to two generations annually. In southern locations with three generations, moth flights and oviposition typically occur in May, late June, and August. In locations with four generations, adults are active in April, June, July, and August-September.

\section{Egg}

Eggs are deposited in irregular clusters of about 15 to 20 . The eggs are oval, flattened, and creamy white in color, usually with an iridescent appearance. The eggs darken to a beige or orangish tan color with age. Eggs normally are deposited on the underside of leaves, and overlap like shingles on a roof or fish scales. Eggs measure about $1.0 \mathrm{~mm}$ in length and $0.75 \mathrm{~m}$ in width. The developmental threshold for eggs is about 15 degrees $\mathrm{C}$. Eggs hatch in four to nine days.

1. This document is EENY-156, one of a series of Featured Creatures from the Entomology and Nematology Department, Florida Cooperative Extension Service, Institute of Food and Agricultural Sciences, University of Florida. Published: September 2000. This document is also available on Featured Creatures Website at http://creatures.ifas.ufl.edu. Please visit the EDIS Website at http://edis.ifas.ufl.edu. Additional information on these organisms, including many color photographs, is available at the Entomology and Nematology Department website at http://entnemdept.ifas.ufl.edu/.

2. J. L. Capinera, professor/chairman, Entomology and Nematology Department, Cooperative Extension Service, Institute of Food and Agricultural Sciences, University of Florida, Gainesville, FL 32611.

The Institute of Food and Agricultural Sciences is an equal opportunity/affirmative action employer authorized to provide research, educational information and other services only to individuals and institutions that function without regard to race, color, sex, age, handicap, or national origin. For information on obtaining other extension publications, contact your county Cooperative Extension Service office. Florida Cooperative Extension Service/Institute of Food and Agricultural Sciences/University of Florida/Christine Taylor Waddill, Dean. 


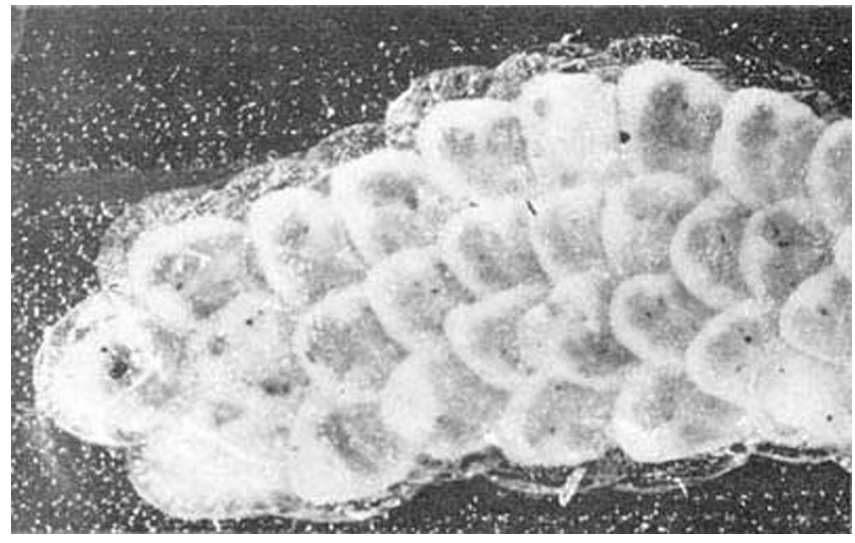

Figure 1. Eggs, soon after being laid, of the European corn borer, Ostrinia nubilalis (Hubner). Credits: USDA

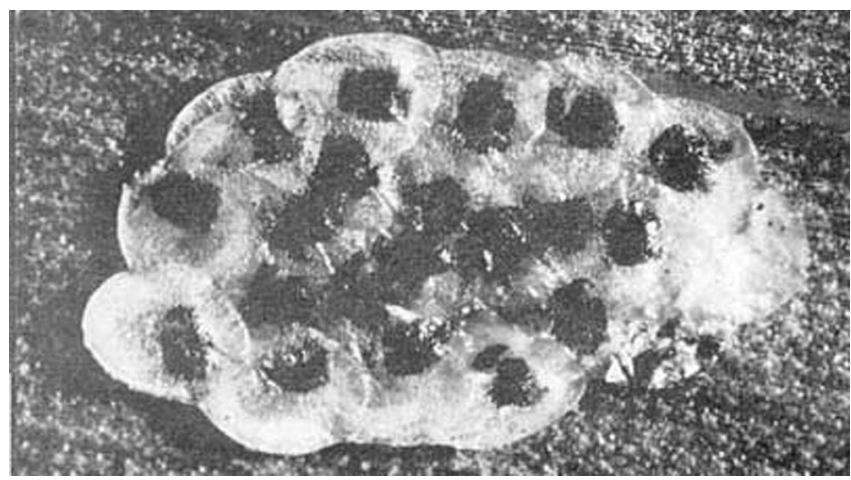

Figure 2. Eggs, which are about ready to hatch, of the European corn borer, Ostrinia nubilalis (Hubner). Credits: USDA

\section{Larva}

Larvae tend to be light brown or pinkish gray in color dorsally, with a brown to black head capsule and a yellowish brown thoracic plate. The body is marked with round dark spots on each body segment. The developmental threshold for larvae is about 11 degrees C. Larvae normally display six instars. Head capsule widths are about $0.30,0.46,0.68,1.03,1.66$, and $2.19 \mathrm{~mm}$ in instars 1 through 6 , respectively. Mean body lengths during the six instars are about $1.6,2.6,4.7,12.5,14.5$, and $19.9 \mathrm{~mm}$, respectively. Young larvae tend to feed initially within the whorl, especially on the tassel. When the tassel emerges from the whorl, larvae disperse downward where they burrow into the stalk and the ear. Mortality tends to be high during the first few days of life, but once larvae establish a feeding site within the plant survival rates improve. Larvae in the final instar overwinter within a tunnel in the stalk of corn, or in the stem of another suitable host. Duration of the instars varies with temperature. Under field conditions development time was estimated at 9.0, $7.8,6.0,8.8,8.5$, and 12.3 days for instars 1 through 6 , respectively, for a mean total development period of about 50 days, but this varies considerable from year to year according to weather conditions.

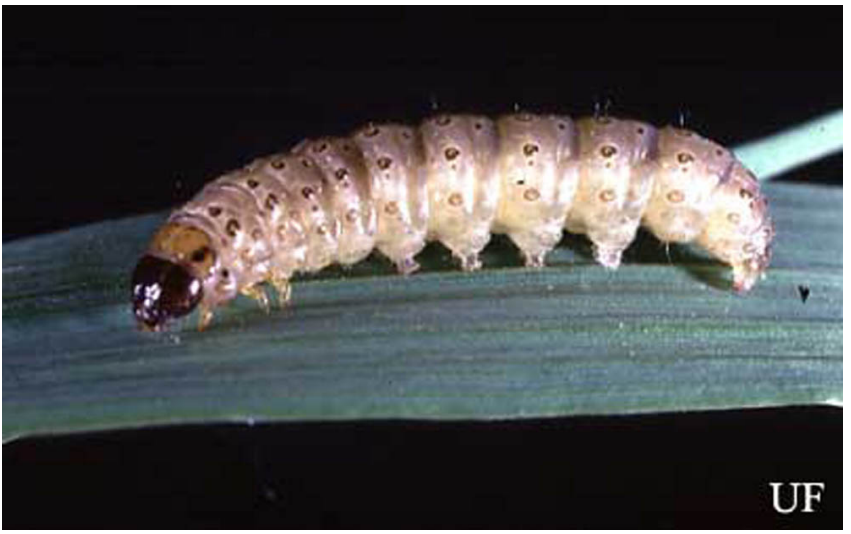

Figure 3. Mature larva of the European corn borer, Ostrinia nubilalis (Hubner). Credits: John L. Capinera, University of Florida

\section{Pupa}

Pupae usually occur in April or May, and then later in the year if more than one generation occurs. The pupa is normally yellowish brown in color. The pupa measures 13 to $14 \mathrm{~mm}$ in length and 2 to $2.5 \mathrm{~mm}$ in width in males and 16 to $17 \mathrm{~mm}$ in length and 3.5 to $4 \mathrm{~mm}$ in width in females. The tip of the abdomen bears five to eight recurved spines that are used to anchor the pupa to its cocoon. The pupa is ordinarily, but not always, enveloped in a thin cocoon formed within the larval tunnel. Duration of the pupal stage under field conditions is usually about 12 days. The developmental threshold for pupae is about 13 degrees $\mathrm{C}$.

\section{Adult}

The moths are fairly small, with males measuring 20 to $26 \mathrm{~mm}$ in wingspan, and females 25 to $34 \mathrm{~mm}$. Female moths are pale yellow to light brown in color, with both the forewing and hind wing crossed by dark zigzag lines and bearing pale, often yellowish, patches. The male is darker in color, usually pale brown or grayish brown, but also with dark zigzag lines and yellowish patches. Moths are most active during the first three to five hours of darkness. The sex pheromone has been identified as 11-tetradecenyl acetate, but eastern and western 
strains differ in production of $\mathrm{Z}$ and $\mathrm{E}$ isomers. The preoviposition period averages about 3.5 days. Duration of oviposition is about 14 days, with oviposition averaging 20 to 50 eggs per day. The female often deposits 400 to 600 eggs during her life span. Total adult longevity is normally 18 to 24 days.

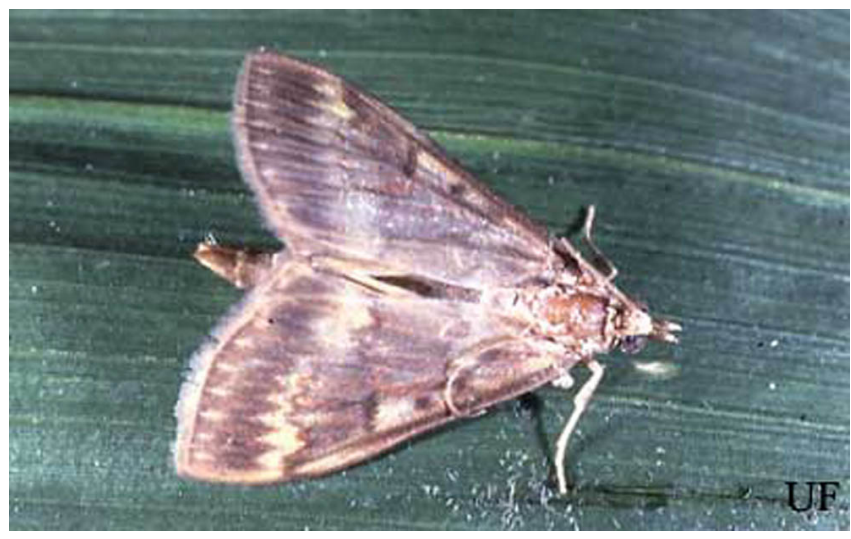

Figure 4. Adult male European corn borer, Ostrinia nubilalis (Hubner). Credits: John L. Capinera, University of Florida

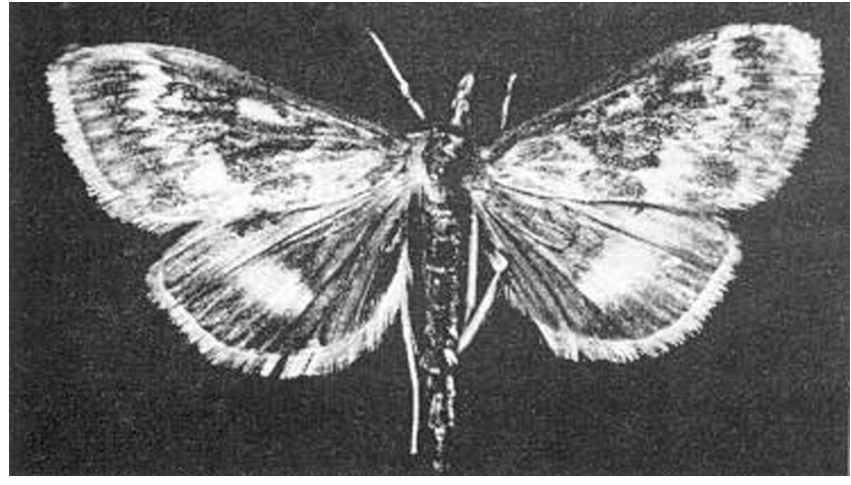

Figure 5. Color comparisons of the adult male (top) and female (bottom) European corn borer, Ostrinia nubilalis (Hubner). Credits: USDA

\section{Host Plants}

European corn borer has a very wide host range, attacking practically all robust herbaceous plants with a stem large enough for the larvae to enter. However, the eastern strain accounts for most of the wide host range, the western strain feeding primarily on corn. Vegetables other than corn tend to be infested if they are abundant before corn is available, or late in the season when senescent corn becomes unattractive for oviposition; snap and lima beans, pepper, and potato are especially damaged. In North Carolina, for example, potato is more attractive than corn at peak emergence of the first moth flight, and more heavily damaged. Other crops sometimes attacked include buckwheat, grain corn, hop, oat, millet, and soybean, and such flowers as aster, cosmos, dahlia, gladiolus, hollyhock, and zinnia. Some of the common weeds infested include barnyardgrass, Echinochoa crus-galli; beggarticks, Bidens spp.; cocklebur, Xanthium spp.; dock, Rumex spp.; jimsonweed, Datura spp.; panic grass, Panicum spp.; pigweed, Amaranthus spp.; smartweed, Polygonum spp.; and others. A good list of host plants is given by Caffrey and Worthley (1927).

\section{Natural Enemies}

Native predators and parasites exert some effect on European corn borer populations, but imported parasitoids seem to be more important. Among the native predators that affect the eggs and young larvae are the insidious flower bug, Orius insidious (Say) (Hemiptera: Anthocoridae); green lacewings, Chrysoperla spp. (Neuroptera: Chrysopidae); and several ladybird beetles (Coleoptera: Coccinellidae). Insect predators often eliminate 10 to $20 \%$ of corn borer eggs. Avian predators such as downy woodpecker, Dendrocopos pubescent (Linnaeus); hairy woodpecker, D. villosus (Linnaeus); and yellow shafted flicker, Colaptes auratus (Linnaeus) have been known to eliminate 20 to $30 \%$ of overwintering larvae.

Exotic parasitoids numbering about 24 species have been imported and released to augment native parasitoids. About six species have successfully established. Among the potentially important species is Lydella thompsoni Herting (Diptera: Tachinidae), which may kill up to $30 \%$ of second generation borers in some areas, but has disappeared or gone into periods of low abundance in other areas. Other exotic parasitoids that sometimes account for more than trivial levels of parasitism are Eriborus terebrans Gravenhorst (Hymenoptera: Ichneumonidae), Simpiesis viridula (Hymenoptera: Eulophidae), and Macrocentris grandii Goidanich (Hymenoptera: Braconidae). A comprehensive review of biological control agents imported in the first half of the 1900s was published by Baker et al. (1949). 


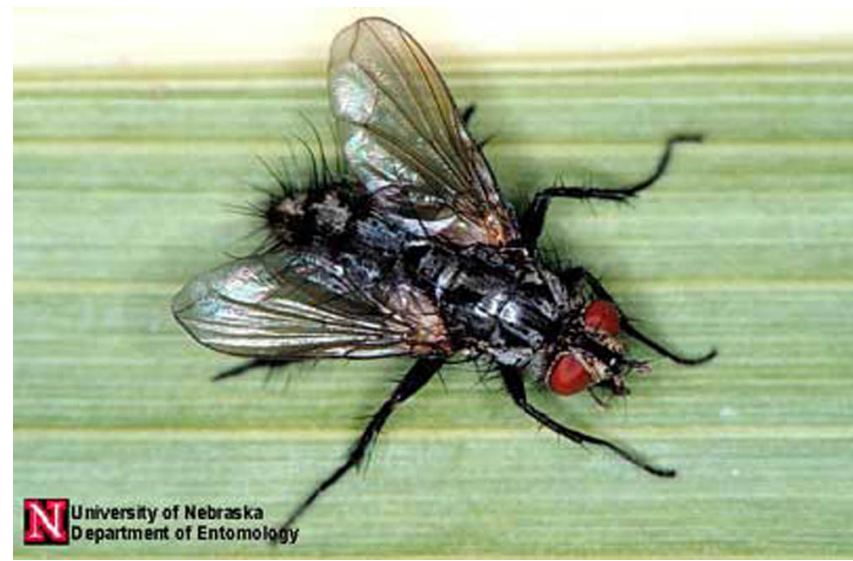

Figure 6. Lydella thompsoni GHerting (Diptera:

Tachinidae), a parasitiod of the European corn borer, Ostrinia nubilalis (Hubner). Credits: Jim Kalisch and Tom Hunt, University of Nebraska - Lincoln (http://entomology.unl.edu/)

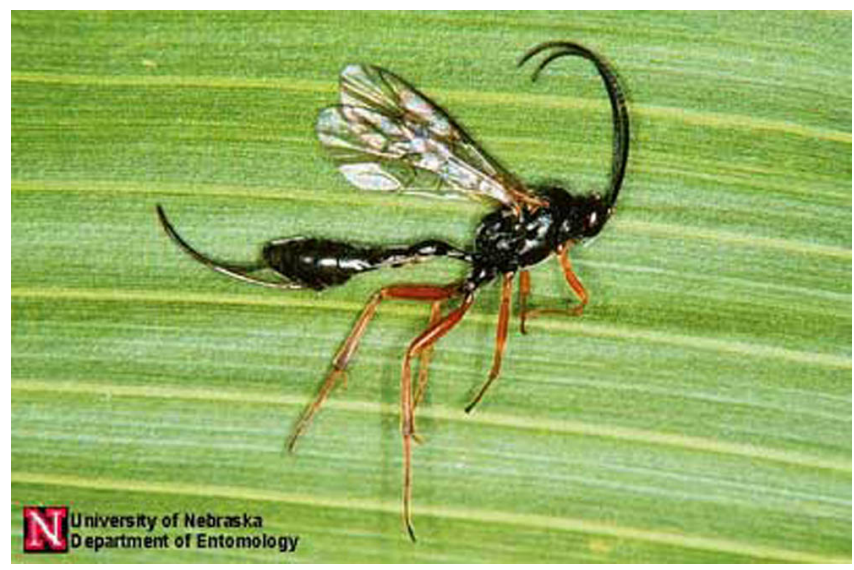

Figure 7. Eriborus terebrans Gravenhorst (Hymenoptera: Ichneumonidae), a parasitiod of the European corn borer, Ostrinia nubilalis. Credits: Jim Kalisch and Tom Clark, University of Nebraska - Lincoln (http://entomology.unl.edu/)

Several microbial disease agents are known from corn borer populations. The common fungi Beauveria bassiana and Metarhizium anisopliae are sometimes observed, especially in overwintering larvae. The most important pathogen seems to be the microsporidian Nosema pyrausta, which often attains $30 \%$ infection of larvae and sometimes 80 to $95 \%$ infection. It creates chronic, debilitating infections that reduce longevity and fecundity of adults, and reduces survival of larvae that are under environmental stress.

Life table studies conducted on corn borer populations in Quebec with a single annual generation perhaps provide insight into the relative importance

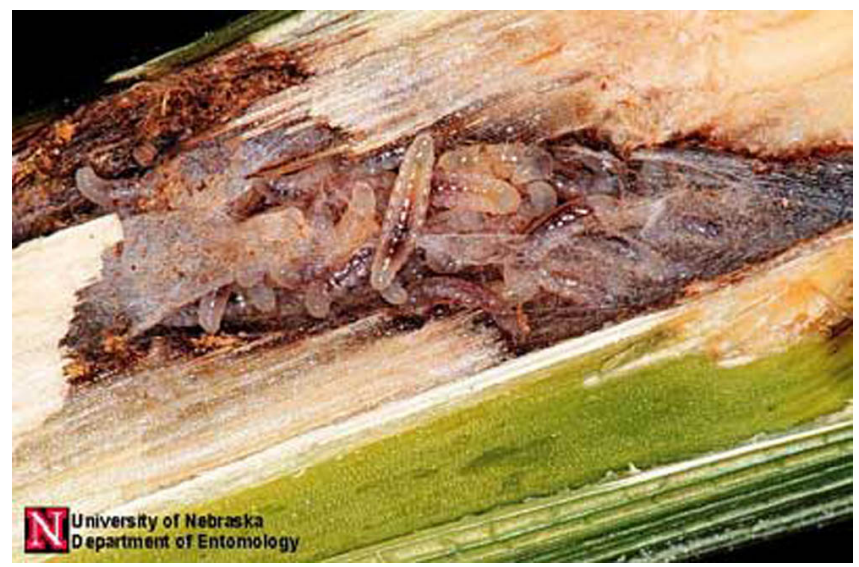

Figure 8. Larva of Macrocentrus grandii Goidanich, a braconid parasitiod of the European corn borer, Ostrinia nubilalis (Hubner). Credits: Jim Kalisch and Tom Clark, University of Nebraska - Lincoln (http://entomology.unl.edu/)

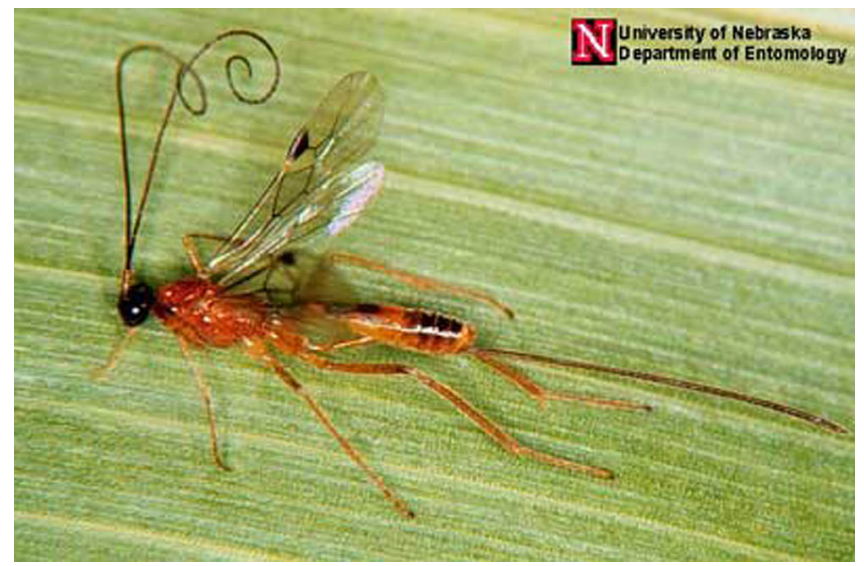

Figure 9. Adult Macrocentrus grandii Goidanich, a braconid parasitiod of the European corn borer, Ostrinia nubilalis (Hubner). Credits: Jim Kalisch and Tom Clark, University of Nebraska - Lincoln

(http://entomology.unl.edu/)

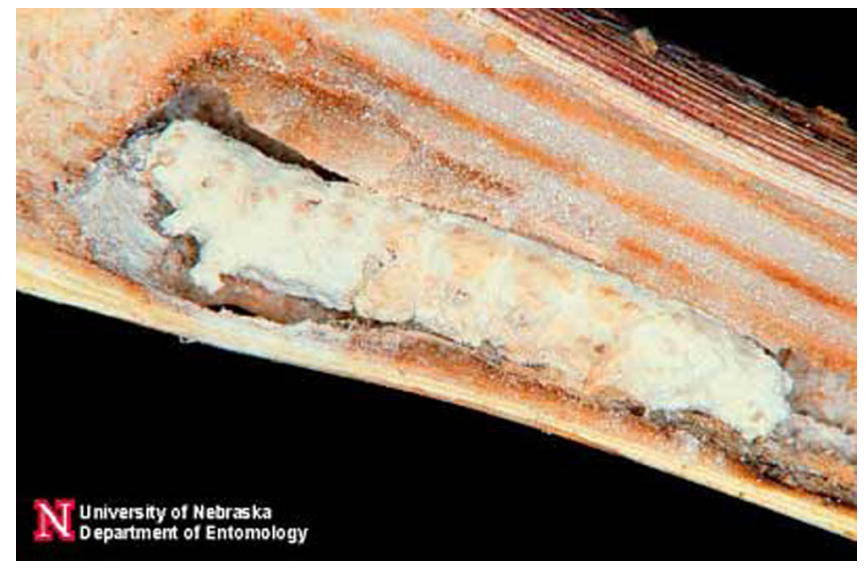

Figure 10. European corn borer, Ostrinia nubilalis (Hubner), infected with the fungus Beauveria bassiana. Credits: Jim Kalisch and Tom Clark, University of Nebraska - Lincoln (http://entomology.unl.edu/) 
of mortality factors (Hudon and LeRoux 1986c).

These workers demonstrated that egg mortality (about 15\%) was low, stable and due mostly to predators and parasites. Similarly, mortality of young larvae, due principally to dispersal, dislodgement, and plant resistance to feeding was fairly low (about $15 \%$ ) but more variable. Mortality of large larvae during the autumn (about 22\%) and following spring (about $42 \%$ ) was due to a number of factors including frost, disease and parasitoids, but parasitism levels were low. Pupal mortality (about 10\%) was low and stable among generations. The factor that best accounted for population trends was survival of adults. Dispersal of moths and disruption of moth emergence by heavy rainfall are thought to account for high and variable mortality (68 to $98 \%$, with a mean of $95 \%$ ), which largely determines population size of the subsequent generation. Overall generation mortality levels were high, averaging $98.7 \%$.

\section{Weather}

There are many reports that weather influences European corn borer survival. Heavy precipitation during egg hatch, for example, is sometimes given as an important mortality factor. Low humidity, low nighttime temperatures, and heavy rain and wind are detrimental to moth survival and oviposition.

However, during a 10-year, 3-state study, Sparks et al. (1967) reported no consistent relationship between weather and survival.

\section{Damage}

This is a very serious pest of both sweet corn and grain corn, and before the availability of modern insecticides this insect caused very marked reductions in corn production. Young larvae feed on tassels, whorl and leaf sheath tissue; they also mine midribs and eat pollen that collects behind the leaf sheath. Sometimes they feed on silk, kernels, and cobs, or enter the stalk. Older larvae tend to burrow into the stalk and sometimes the base of the corn ear, or into the ear cob or kernels. Feeding by older larvae is usually considered to be most damaging, but tunneling by even young larvae can result in broken tassels. The presence of one to two larvae within a corn stalk is tolerable, but the presence of any larvae within the ear of sweet corn is considered intolerable by commercial growers, and is their major concern. European corn borer is considered to be the most important sweet corn pest in northern production areas, and second-generation borers are the principal source of ear damage. Heavily tunneled stalks of grain corn suffer from lodging, reducing the capacity for machine harvesting. Lodging is not a serious threat to sweet corn. Boring by corn borers also allows several fungi to affect corn plants.

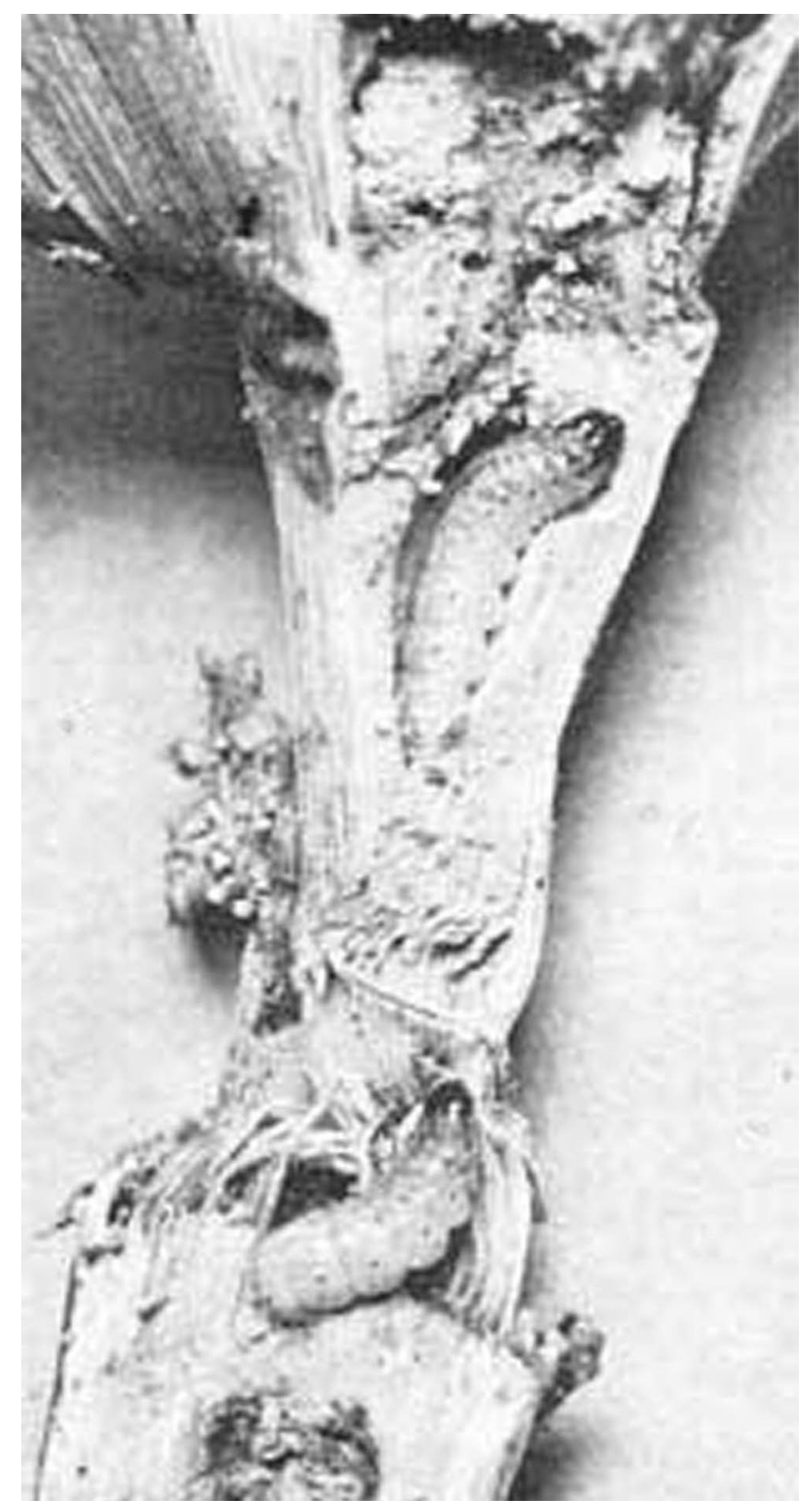

Figure 11. Corn stalk and ear shank cut open to show European corn borer, Ostrinia nubilalis (Hubner), larvae and damage caused by their feeding. Boring in shank causes ear to break off and drop to ground. Credits: USDA 
In crops other than corn, the pattern of damage is variable. European corn borer larvae damage both the stem and fruit of beans, pepper, and cowpea. In celery, potato, rhubarb, Swiss chard, and tomato, it is usually the stem tissue that is damaged. In beet, spinach, and rhubarb, leaf tissue may be injured. Entry of borers into plant tissue facilitates entry of plant pathogens. The incidence of potato blackleg caused by the bacterium Erwinia carotovora atroseptica, for example, is higher in potato fields with stems heavily infested by corn borers. Direct damage by corn borers to potato vines, however, results in negligible yield loss.

\section{Management}

\section{Sampling}

Moths can be sampled with blacklight and pheromone traps, and catches by these traps are correlated. Pheromones attract only males, whereas both sexes are captured in traps with a blacklight. Blacklight traps tend to be more reliable, but light traps can capture large numbers of other insects, necessitating a great deal of sorting.

Pheromone-baited water pan traps seem to be the most efficient method of adult monitoring. Trap catches are usually used to initiate intensive in-field scouting for egg masses, as moth catches are only roughly correlated with density.

Techniques other than adult capture can be used to estimate borer phenology. Plant phenology can be used to predict corn borer development. Thermal summations are also highly predictive. Moths seek shelter during the daylight hours in dense grass and weeds near corn fields. Flushing moths from such habitats gives an estimate of population densities. Eggs can be sampled by visual examination, but this is a very time-consuming effort.

\section{Insecticides}

Liquid formulations of insecticide are commonly applied to protect against damage to corn, particularly from the period of early tassel formation until the corn silks are dry. Recommendations vary from a single application prior to silking, to weekly applications. Liquid applications are usually made to coincide with egg hatch in an effort to prevent infestation. If corn borers are present in a field, however, the critical treatment time is just before the tassels emerge, or at tassel emergence from the whorl. This plant growth period is significant because the larvae are active at this time and more likely to contact insecticide. A popular alternative to liquid insecticides is the use of granular formulations, which can be dropped into the whorl for effective control of first generation larvae because this is where young larvae tend to congregate. Insecticide is more persistent when applied in a granular formulation. In grain corn, insecticide applications for suppression of second generation corn borers can be made outside the corn fields in areas of thick grass, or action sites, where adults tend to aggregate. This approach has not been assessed for sweet corn. For borer suppression on potato, a single application of insecticide timed to coinide with the presence of first instar larvae provides optimal yield.

Insect Management Guide for Field Crops

Insect Management Guide for Vegetables

Insect Management Guide for Ornamentals

\section{Cultural Practices}

Destruction of stalks, the overwintering site of larvae, has long been recognized as an important element of corn borer management. Disking is not adequate; plowing to a depth of $20 \mathrm{~cm}$ is necessary for destruction of larvae. Mowing of stalks close to the soil surface eliminates greater than $75 \%$ of larvae, and is especially effective when combined with plowing. Minimum tillage procedures, which leave considerable crop residue on the surface, enhance borer survival.

Early planted corn is taller and attractive to ovipositing female moths, so late planting has been recommended, but this is useful mostly in areas with only a single generation per year. If a second generation occurs, such late planted corn is heavily damaged.

\section{Host Plant Resistance}

Extensive breeding research has been conducted, and resistance has been incorporated into grain corn, especially against corn borer populations with only a 
single annual generation. A principal factor in seedling resistance to young larvae is a chemical known as DIMBOA, which functions as a repellent and feeding deterrent. It has proven difficult to incorporate the known resistance factors into sweet corn without degradation of quality.

Pepper cultivars differ in their susceptibility to corn borer. Hot pepper cultivars are most resistant, and most green bell peppers are susceptible.

\section{Biological Control}

Biological control has been attempted repeatedly in sweet corn and other vegetables susceptible to European corn borer attack. Bacillus thuringiensis products can be as effective as many chemical insecticides, but often prove to be less effective than some. Most single-factor approaches, with the exception of newer formulations of Bacillus thuringiensis, have proven to be erratic. Release of native Trichogramma spp. (Hymenoptera:

Trichogrammatidae), for example, provides variable and moderate levels of suppression.

\section{Selected References}

Baker, W.A., W.G. Bradley, and C.A. Clark. 1949. Biological control of the European corn borer in the United States. USDA Tech. Bull. 983.185 pp.

Beck, S.D. 1987. Developmental and seasonal biology of Ostrinia nubilalis. Pages 59-96 in G.E. Russell (ed.). Agricultural Zoology Reviews, Vol. 2. Intercept, Wimborne, Dorset.

Caffrey, D.J. and L.H. Worthley. 1927. A progress report on the investigations of the European corn borer. USDA Bull. 1476. 154 pp.

Capinera, J.L. 2001. Handbook of Vegetable Pests. Academic Press, San Diego. 729 pp.

Hudon, M. and E.J. LeRoux. 1986a. Biology and population dynamics of the European corn borer (Ostrinia nubilalis) with special reference to sweet corn in Quebec. I. Systematics, morphology, geographical distribution, host range, economic importance. Phytoprotection 67:39-54.
Hudon, M. and E.J. LeRoux. 1986b. Biology and population dynamics of the European corn borer (Ostrinia nubilalis) with special reference to sweet corn in Quebec. II. Bionomics. Phytoprotection 67:81-92.

Hudon, M. and E.J. LeRoux. 1986c. Biology and population dynamics of the European corn borer (Ostrinia nubilalis) with special reference to sweet corn in Quebec. III. Population dynamics and spatial distribution. Phytoprotection 67:93-115.

Hudon, M., E.J. LeRoux, and D.G. Harcourt. 1989. Seventy years of European corn borer (Ostrinia nubilalis) research in North America. Pages 53-96 in G.E. Russell (ed.). Agricultural Zoology Reviews. Vol. 3. Intercept, Wimborne, Dorset, UK.

Nault, B.A. and G.G. Kennedy. 1996a. Timing insecticide applications for managing European corn borer (Lepidoptera: Pyralidae) infestations in potato. Crop Prot. 15:465-471.

Nault, B.A. and G.G. Kennedy. 1996b. Sequential sampling plans for use in timing insecticide applications for control of European corn borer (Lepidoptera: Pyralidae) in potato. J. Econ. Entomol. 89:1468-1476.

Nault, B.A. and G.G. Kennedy. 1996c. Evaluation of Colorado potato beetle (Coleoptera: Chrysomelidae) defoliation with concomitant European corn borer (Lepidoptera: Pyralidae) damage on potato yield. J. Econ. Entomol. 89:475-480.

Sparks, A.N., H.C. Chiang, C.A. Triplehorn, W.D. Guthrie, and T.A. Brindley. 1967. Some factors influencing populations of the European corn borer, Ostrinia nubilalis (Hübner) in the north central states: resistance of corn, time of planting and weather conditions Part II, 1958- 1962. Iowa Agric. Exp. Stn. Res. Bull. 559. 103 pp. 